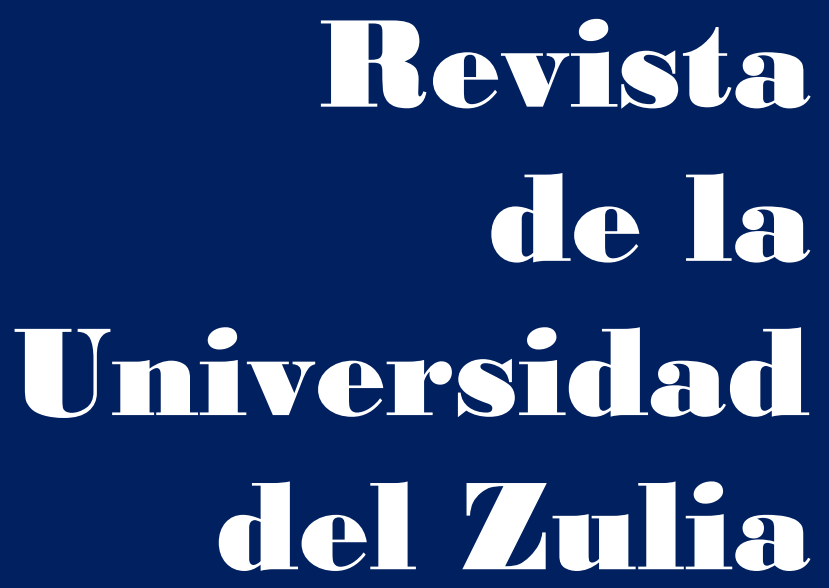

Fundada en 1947

por el Dr. Jesús Enrique Lossada

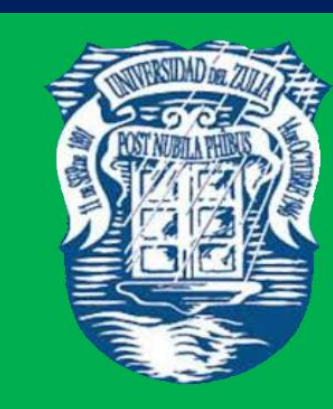

Ciencias del

Agrad,

Ingemiería

y Tecinología

\section{Aกัต 13 No $\mathbf{3 6}$} Enero - Abril 2022

Tercera Épaca

Maracailbo-Venezuela 
REVISTA DE LA UNIVERSIDAD DEL ZULIA. $3^{a}$ época. Año $13 \mathrm{~N}^{\circ}$ 36, 2022

Olha Milashovska et al. /// The potential of applying blockchain technologies in various sectors ... 288-304 DOI: http://dx.doi.org/10.46925//rdluz.36.19

\title{
The potential of applying blockchain technologies in various sectors of the digital economy
}

\author{
Olha Milashovska* \\ Natalia Liba** \\ Oksana Korolovych*** \\ Nataliia Smyrnova**** \\ Valeria Slatvinska*****
}

\begin{abstract}
The objective of the article is to determine the potential of blockchain technologies in various sectors of the digital economy, in the case of the countries of the European Union. Methodology. The research assesses the use of digital technologies to ensure the country's digital development, based on data from the European Commission and the Digital Economy and Society Index (DESI). On the basis of DESI, a cluster diagram was created to determine the potential for the use of blockchain technology in the countries of the European Union. Results. The potential for the use of blockchain technology in each country depends and is significantly connected with the introduction of different technologies and the availability of the Internet, the provision of digital services by the government, the development of human capital. The main potential advantages of the technology include the following: acceleration of globalization processes, ensuring the country's transition from real production to technological development, change of established business models, transformation and optimization of value chains of different sectors of the economy by reducing costs; transformation of the nature of mediation due to technological changes; the use of cryptocurrency to achieve the consensus of economic agents on the allocation of scarce resources on a global scale.

KEY WORDS: digital technology; digitization; Information and Communication Technologies; Economy.
\end{abstract}

*Professor, Head of the Department of Hotel and Restaurant Business, doctor of science, Department of Hotel and Restaurant Business, Faculty of Management and Hospitality Industry, Mukachev State University. ORCID: https://orcid.org/0000-0003-2381-7534. E-mail: smsllll1@rambler.ru

** Doctor of science, Associate Professor at the Accounting, Taxation and Marketing Department, Accounting, Taxation and Marketing Department, Faculty of Economics, Management and Engineering, Mukachev State University. ORCID: https://orcid.org/0000-0001-7053-8859. E-mail: smslllll@rambler.ru

*** PhD in Economic, Associate Professor at the Accounting, Taxation and Marketing Department, Accounting, Taxation and Marketing Department, Faculty of Economics, Management and Engineering, Mukachev State University. ORCID: https://orcid.org/0000-0001-5878-0925. E-mail: oxykk@yahoo.com

**** Ph.D., associate professor, Faculty of International Economics; Department of Marketing, Odessa. National University of Economics. ORCID: https://orcid.org/0000-0002-7482-4606 E-mail: petuniya3@gmail.com

***** Teacher, Department of Criminal Law, Process and Criminalistics, International Humanitarian University. ORCID: https://orcid.org/0000-0002-6082-981X. E-mail: slatvinskaya_valeriya@ukr.net

Recibido: 04/10/2021

Aceptado: 01/12/2021 


\section{El potencial de aplicar tecnologías blockchain en varios sectores de la economía digital}

RESUMEN

El objetivo del artículo es determinar el potencial de las tecnologías blockchain en varios sectores de la economía digital, en el caso de los países de la Unión Europea. Metodología. La investigación evalúa el uso de tecnologías digitales para asegurar el desarrollo digital del país, basándose en los datos de la Comisión Europea y el Índice de Economía y Sociedad Digital (IESD). Sobre la base de IESD, se creó un diagrama de clúster para determinar el potencial de uso de la tecnología blockchain en los países de la Unión Europea. Resultados. El potencial de uso de la tecnología blockchain en cada país depende y está significativamente conectado con la introducción de diferentes tecnologías y la disponibilidad de Internet, la provisión de servicios digitales por parte del gobierno, el desarrollo del capital humano. Las principales ventajas potenciales de la tecnología incluyen las siguientes: aceleración de los procesos de globalización, asegurando la transición del país de la producción real al desarrollo tecnológico, cambio de modelos de negocio establecidos, transformación y optimización de cadenas de valor de diferentes sectores de la economía mediante la reducción de costos; transformación de la naturaleza de la mediación debido a cambios tecnológicos; el uso de la criptomoneda para lograr el consenso de los agentes económicos sobre la asignación de recursos escasos a escala global.

PALABRAS CLAVES: tecnología digital; digitalización; Tecnologías de la Información y Comunicación; Economía.

\section{Introduction}

Blockchain as a technology has demonstrated the ability to eliminate intermediaries, streamlining transactions based on registers in various sectors of the economy, from cryptocurrency to centralized voting. In many countries, blockchain-based technologies ensure the transparency of transactions between different sectors and market participants, helping to reduce the level of corruption and increase the trust of various economic agents. "Blockchains as digitized decentralized ledgers make it possible to conducts records of single-rank transaction records, thus, eliminating the necessity for trusted third parties to intervene" (Bhimani, Hausken \& Arif, 2021). Currently, the blockchain technology is considered as the most significant invention after the Internet. While the latter brings people together to implement business processes online, the former can solve the problem of trust through peer-to-peer networking and public key cryptography (Efanov \& Roschin, 2018). 
REVISTA DE LA UNIVERSIDAD DEL ZULIA. $3^{a}$ época. Año $13 \mathrm{~N}^{\circ}$ 36, 2022

Olha Milashovska et al. /// The potential of applying blockchain technologies in various sectors ... 288-304 DOI: http://dx.doi.org/10.46925//rdluz.36.19

The importance of the blockchain determines the relevance of studying the potential impact and applying the technology in different sectors of the digital economy, as well as identifying possible effects of the impact on digitalization.

The purpose of the academic paper lies in determining the potential of blockchain technologies in various sectors of the digital economy on the example of EU countries differing in the level of the ICT sector development.

\section{Literature Review}

Since the end of the twentieth century, a lot of scientific works explain the concept of digitization and the digital economy; however, since 1997, the relevant regional aspects have remained poorly understood. Herewith, there are no agreed definitions of the digital sector, digital products or digital transactions in the scientific literature (International Monetary Fund, 2018). Consequently, the conceptual paradigm of the digital economy envisages both activities based on online platforms and activities involving the use of digitized data. This ambiguous definition of the digital economy leads, among other things, to conflicting estimates of the size of the digital economy (Góźdź \& Van Oosterom, 2016).

Scientists use various indicators to assess technological progress outside the digital economy. Initially, the digital economy was defined as an economic system characterized by the widespread use of ICT, covering basic infrastructure, e-business and e-commerce. Subsequently, the scope of the concept has expanded at the same pace as the development and evolution of digital technologies. Therefore, the digital density index, developed in 2015, contains 50 indicators grouped into 4 areas of activity and 18 groups of indicators (Szeles \& Simionescu, 2020). In 2016, as part of the Europe 2020 Strategy, the Digital Economy and Society Index (DESI) was created in order to reflect the performance results of EU member states in the field of digital competitiveness. Currently, it is estimated that the size of the digital economy ranges from 4,5 to 15,5\% of world GDP (UNCTAD, 2019). By lapse of time, a great number of investigations have examined the major drivers, dimensions and indicators of the digital economy, focusing on specific dimensions of the digital economy and using particular analysis between countries. E-commerce, Internet use and human resources in ICT are some of the variables commonly used to assess the digital economy, also included in the most popular digital economy indices such as DESI. 
REVISTA DE LA UNIVERSIDAD DEL ZULIA. $3^{a}$ época. Año $13 \mathrm{~N}^{\circ}$ 36, 2022

Olha Milashovska et al. /// The potential of applying blockchain technologies in various sectors ... 288-304 DOI: http://dx.doi.org/10.46925//rdluz.36.19

Conceptually, blockchain is a distributed database containing transaction records that are shared by participants. Each transaction is confirmed by consensus of the majority of participants, making it impossible for fraudulent transactions to go through collective confirmation. Once a record is created and accepted by blockchain, it can never be changed or deleted (Efanov \& Roschin, 2018). Blockchain, like the Internet, is an open, global infrastructure that provides an opportunity to companies and individuals, carrying out transactions, to eliminate intermediaries, reducing transaction costs and working times through third parties. The technology is based on the structure of the distributed book and the consensus process. The structure makes it possible to create a digital ledger of transactions and use it between distributed computers in the network. The register is not owned or controlled by a single central authority or company it can be viewed by all network users (Underwood, 2016).

Blockchain (Tripoli \& Schmidhuber, 2018) is derived from the terms "block" and "chain", a list of transactions known as the block connected with the encryption method. Blockchain is a peer-to-peer blockchain managed by a network of peer partners used to store and retrieve information. The block header and transactions are included in each block. The hash, common measure, one-time value, and root value of the previous block header are stored in the block header. It is impossible to change the information in the block. The main use of blockchain is to eliminate inconsistencies (Baralla et al., 2018). Blockchain can be represented by digital public records documenting bitcoin exchanges or cutting-edge cash at record demand. Upon completion, the block enters blockchain as immutable information. Each block contains the hash of the previous block, the data of the current block and its own hash data. Taking into consideration that blockchain is a complex record with limited capabilities, when data is placed in a block, it is extremely difficult to change it; for this reason, this kind of innovation is used in programs such as money management and intellectual property. Blockchain provides the opportunity for customers to conduct their web applications on their local and primitive computers. The blockchain tool has no servers; it is restricted to any place where customers can have or manage their data or applications running on their devices. Blockchain is a distributed ledger of transactions. This makes it possible for community members to share data with other services without the involvement of a third party and to track the transaction. Instead of storing information on a single server, 
REVISTA DE LA UNIVERSIDAD DEL ZULIA. $3^{a}$ época. Año $13 \mathrm{~N}^{\circ}$ 36, 2022

Olha Milashovska et al. /// The potential of applying blockchain technologies in various sectors ... 288-304 DOI: http://dx.doi.org/10.46925//rdluz.36.19

it is shared between multiple servers, making it extremely difficult to change or delete records. Protection against unauthorized access includes a trademark, as well as a method ensuring that all data entered into the blockchain is reliable, creating public confidence (Corallo et al., 2018). Peer-to-peer networks are used to distribute and support blockchains. A network can exist without a centralized authority or a server controlling it, forasmuch as it is a distributed ledger and its data quality can be maintained through database replication and computational trust. Blockchain technology is a type of distributed ledger technology. In order to create a secure and distributed consensus, not all distributed ledgers use a chain of blocks. The blockchain structure distinguishes it from other types of distributed registers. In blockchain, data is collected together and encrypted. A distributed ledger is a database covering multiple nodes or computing devices. Each node duplicates and saves a copy of the ledger. Each node-member of the network is updated independently. The cost of trust is greatly reduced by distributed ledger technology. Constructions and structures of the distributed ledger can help reduce dependence on banks, governments, lawyers, notaries and officials in compliance with regulatory requirements. Corda, developed by R3, is an example of a distributed ledger.

The scientific literature explores the issue of using blockchain technologies in the following areas of the digital economy, namely: the financial system at the macro and micro levels (in particular, financial and technological companies) (Vovchenko et al., 2017; Karapetyan et al., 2019), insurance system, public administration system (Babkin et al., 2017; Britchenko \& Cherniavska, 2019), infrastructure (Abodei et al., 2019), e-commerce system, industry, agriculture (for supply chain management in agriculture) (Tripoli \& Schmidhuber, 2018; Baralla et al., 2018; Sajja et al., 2021), intellectual property, education, health care (Dorofeyev et al., 2018; Muminova et al., 2020). Blockchain is also being actively implemented in the tourism sector, especially in island countries (Treiblmaier et al., 2020). For instance, the Caribbean countries have launched the first legal digital means of payment; Aruba has developed a blockchain platform in order to ensure the growth of tax revenues from tourism (Kwok \& Koh, 2019). One of the sectors where blockchain technologies are being introduced at a rapid pace is the financial sector. Babkin et al. (2017) have systematized the features of different countries in the implementation of state regulatory mechanisms of blockchain as follows: creating a favourable climate for the development of new digital technologies 
REVISTA DE LA UNIVERSIDAD DEL ZULIA. $3^{a}$ época. Año $13 \mathrm{~N}^{\circ}$ 36, 2022

Olha Milashovska et al. /// The potential of applying blockchain technologies in various sectors ... 288-304 DOI: http://dx.doi.org/10.46925//rdluz.36.19

(blockchain), applying technologies in the private, public sector (for instance, for the implementation of infrastructure projects of public-private partnership (Abodei et al., 2019); high growth rates of the cryptocurrency market and the lack of adaptation of tax legislation to the challenges of this trend (Crosby et al., 2016; Yeoh, 2017); for this reason, the potential for receiving revenues to budgets is reduced; the necessity to develop common standards for blockchain regulation at the international level.

Along with this, in the scientific literature, there are few empirical quantitative studies of the potential for using blockchain in the context of the digital economy development. Therefore, the present research is aimed at assessing numerically the potential of technology by measuring the development of digitalization aspects as follows: Connectivity, Digital Public Services, Human Capital, and Integration of Digital Technology.

\section{Methodology}

The first part of the research has identified the major tendencies in the development of the digital economy of the EU in three key sectors, namely: state, private and public. In order to assess the development of the digital economy, the indicators of the Eurostat database (section "Science, Technology and Digital Society", subsection "Digital Economy and Society") have been used by the categories as follows: 1) indicators of ICT use by households and individuals; 2) indicators of ICT use by enterprises; 3) indicators of ICT sector development. The second part of the research has assessed numerically the use of digital technologies in order to ensure the digital development of the country based on data from the European Commission (2021) on the Digital Economy and Society Index (DESI) taking into accounts the aspects as follows: Connectivity, Digital Public Services, Human Capital, and Integration of Digital Technology. Integration of digital technology measures the level of implementing the following indicators in countries, namely: 1) Digital intensity; 2) SMEs with at least a basic level of digital intensity; 3) Digital technologies for businesses; 4) Electronic information sharing; 5) Social media; 6) Big data; 7) Cloud; 8) AI; 9) ICT for environmental sustainability; 10) e-Invoices; 11) Blockchain. Thus, DESI serves as an assessment of the synergistic impact of blockchain together with other technologies on the digital economy. On the basis of DESI, a tree cluster diagram has been constructed in order to visually display the clusters of countries in the context of the digital economy 
REVISTA DE LA UNIVERSIDAD DEL ZULIA. $3^{a}$ época. Año $13 \mathrm{~N}^{\circ}$ 36, 2022

Olha Milashovska et al. /// The potential of applying blockchain technologies in various sectors ... 288-304 DOI: http://dx.doi.org/10.46925//rdluz.36.19

development. A cluster analysis of the EU-27 countries according to DESI sub-index estimates in 2020 has been conducted.

\section{Results}

Accelerated use and expansion of the Internet as a means of communication, mobile Internet, social networks, commercial platforms, usually perceived as digitalization, has had a significant impact on the functioning and state of the economy, on the activities of enterprises, government agencies and individuals. The state of digitization of business and various sectors of the economy varies between countries and regions of the European Union (EU). Each EU country implements its own digitalization model in order to ensure economic growth, productivity and competitiveness.

The EU countries are characterized by the implementation of various models of digital transformation due to differences in the established economic and social policies (Szeles \& Simionescu, 2020). The digital economy is growing rapidly, especially in developing countries; however, the values and indicators of the digital economy are limited and divergent. The core of the digital economy is the "digital sector": that is, the IT / ICT sector

producing basic digital goods and services. The digital economy is defined as "that part of economic production that derives exclusively or primarily from digital technologies with a business model based on digital goods or services, including the digital sector and new digital services". The ICT sector, penetrating into all sectors of the economy, is defined as the "digital economy", the size of which amounts about 5\% of world GDP and 3\% of world employment (Bukht \& Heeks, 2017; Barefoot et al., 2018).

The average value of the share of the ICT sector in the EU-27 GDP was 4,1\% in 20082018, growing by 0,34\% over ten years (Eurostat, 2021a). All countries can be classified according to the level of development of the ICT sector into three groups, namely:

1) high level of development with a share of ICT in GDP of more than 5\%, which includes countries as follows: Malta $-7,97 \%$, Bulgaria - 6,1\%, Hungary - 5,95\%, Sweden 5,94\%, Estonia - 5,38\%;

2) average level of development with the value of the share of ICT in GDP in the range of 3,5-5\%, which includes countries as follows: Latvia $-4,92 \%$, Finland $-4,85 \%$, the Czech Republic - 4,56\%, Denmark - 4,56\%, Croatia - 4,45\%, Germany - 4,4\%, France - 4,31\%, 
REVISTA DE LA UNIVERSIDAD DEL ZULIA. $3^{a}$ época. Año $13 \mathrm{~N}^{\circ}$ 36, 2022

Olha Milashovska et al. /// The potential of applying blockchain technologies in various sectors ... 288-304 DOI: http://dx.doi.org/10.46925//rdluz.36.19

Slovakia - 4,13\%, Iceland - 4,03\%, Belgium - 3,96\%, Romania - 3,74\%, Poland - 3,59\%, Slovenia - 3,59\%, Austria - 3,58\%;

3) low level of development with the share of ICT in GDP less than 3,5\%, which includes countries as follows: Norway $-3,37 \%$, Italy $-3,29 \%$, Spain $-3,28 \%$, Lithuania $3,13 \%$, Greece - 2,49\%.

Accordingly, in the EU countries the share of population employed in the ICT sector (Eurostat, 202lb; 202lc) and the needs of the labour market in ICT professionals differ. The average share of employment in ICT was 2,79\% in the EU-27 in 2009-2018. The largest share of people employed in the ICT sector is observed in the following countries, namely: Malta4,77\%, Sweden - 4,75\%, Estonia - 4,3\%, Latvia - 4,15\%, which can be attributed to the group with the most developed digital economy, where the share of employed population exceeds $4 \%$. The following group of countries with an average employment rate in ICT in the range of $3-4 \%$ is as follows: Finland $-3,79 \%$, Hungary $-3,6 \%$, Denmark $-3,51 \%$, the United Kingdom - 3,43\%, Slovakia - 3,31\%, Germany $-3,16 \%$, Switzerland $-3,16 \%$, the Czech Republic $-3,13 \%$, Norway $-3,08 \%$, France $-3,07 \%$. The group of countries with low employment in ICT (less than 3\%) should include as follows: Belgium - 2,85\%, Bulgaria 2,85\%, Slovenia - 2,72\%, Lithuania - 2,64\%, Austria - 2,63\%, Croatia - 2,57\%, Poland 2,54\%, Romania - 2,52\%, Spain - 2,48\%, Italy - 2,43\%, Greece - 1,51\%.

Over the last ten years (2011-2020), the share of the population using the Internet has increased significantly, which means that the digital economy is developing at a rapid pace, ICTs are penetrating into various spheres of social life. The average value of Internet use by individuals is $88 \%$ in the EU-27 with a deviation of 7,55\%, reaching $99 \%$ in some countries (Figure 1).

For the period of 2010-2019, e-commerce has increased significantly: the share of individuals who made online purchases in the last 12 months in 2010 was $36 \%$, in $2019-60 \%$, in $2020-65 \%$. At the same time, a significant differentiation of countries in the development of e-commerce is observed (Figure 2).

Thanks to ICT, e-government is developing, providing penetration into the public sector of technologies in order to facilitate the interaction of the private sector and individuals with public authorities (Figure 3). Therefore, the share of people using the Internet for interaction with the authorities increased from $41 \%$ in 2011 to $57 \%$ in 2020. 


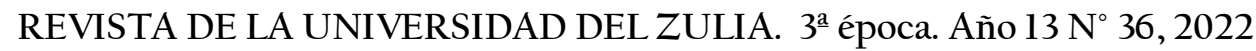
Olha Milashovska et al. /// The potential of applying blockchain technologies in various sectors ... 288-304 DOI: http://dx.doi.org/10.46925//rdluz.36.19

Figure 1. Individuals - internet use, 2011-2020, EU--27, \%

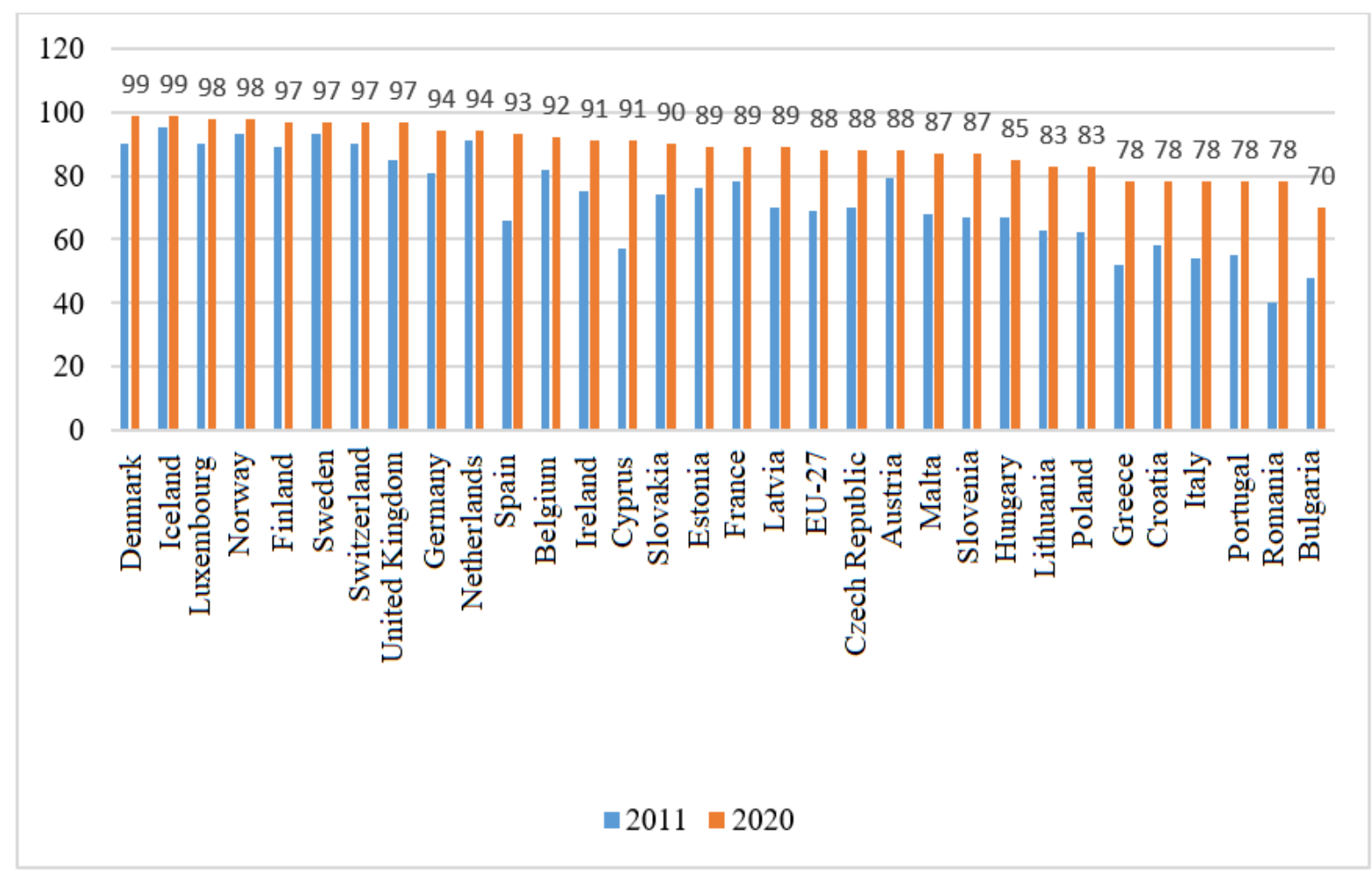

Source: compiled by the authors according to the Eurostat data (202ld).

Figure 2. Internet purchases by individuals (2020 onwards) for last 3 or 12 months in EU-27, 2020 y 2020

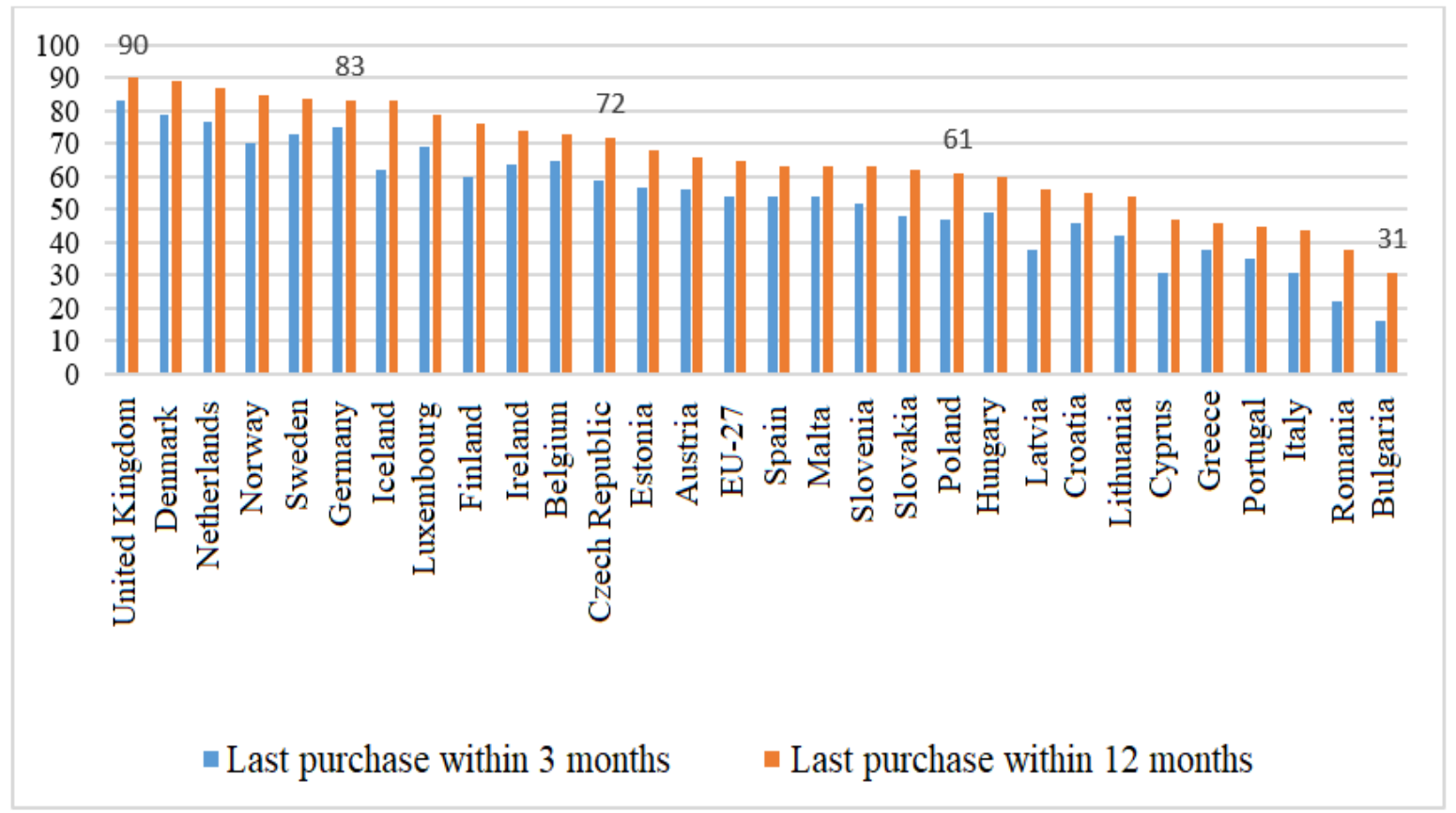

Source: compiled by the authors according to the Eurostat data (202le). 
REVISTA DE LA UNIVERSIDAD DEL ZULIA. $3^{a}$ época. Año $13 \mathrm{~N}^{\circ}$ 36, 2022

Olha Milashovska et al. /// The potential of applying blockchain technologies in various sectors ... 288-304 DOI: http://dx.doi.org/10.46925//rdluz.36.19

Figure 3. Use of ICT at work and activities performed (the share of the population of EU countries using the Internet to interact with the authorities, \% of the total population)

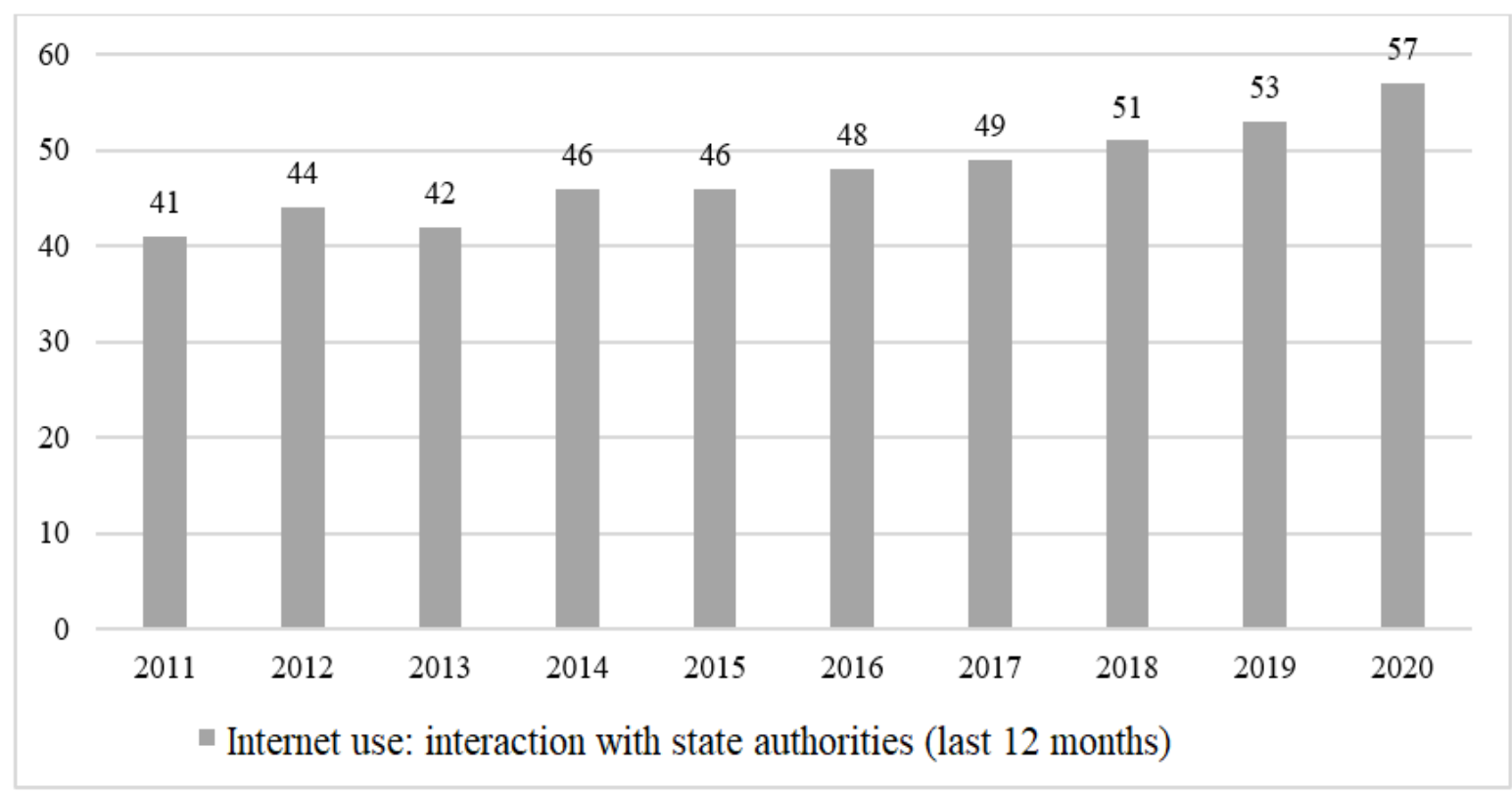

Source: compiled by the authors according to the Eurostat data (202ld).

The most advanced EU countries are characterized by higher assessments for the subindices of the digital economy development (Table 1).

The simultaneous priority of two high marks is typical for different EU countries. For instance, the quality of digital public services is highly assessed in Estonia, Finland, and Sweden; high estimates of human capital and Internet availability are observed in Denmark, Malta, Ireland, Spain, and the Netherlands.

The cluster diagram makes it possible to visually highlight 3 clusters of countries in the context of the digital economy development, depending on the level of their digital proximity, assessed on the basis of DESI (Figure 4).

The first cluster includes the countries as follows (Table 2): Belgium, Croatia, Cyprus, the Czech Republic, France, Germany, Italy, Latvia, Lithuania, Portugal, and Slovenia. In these countries, the average value of the Connectivity sub-index is 11,91, Digital Public Services - 16,76, Human Capital - 11,45, Integration of Digital Technology - 9,49 (Table 2). The second cluster includes the countries as follows: Austria, Denmark, Estonia, Finland, Ireland, Luxembourg, Malta, the Netherlands, Spain, and Sweden. The average values of the subindexes of this cluster are as follows: Connectivity - 14,66, Digital Public Services - 20,90, Human Capital - 14,43, Integration of Digital Technology - 12,11.

The third cluster contains 6 countries as follows: Bulgaria, Greece, Hungary, Poland, Romania, and Slovakia. The average values of the subindexes of the third cluster are as follows: Connectivity - 11,35, Digital Public Services - 11,56, Human Capital - 9,53, Integration of Digital Technology - 6,29. The conducted clustering suggests that the potential for using blockchain technology depends on different indicators of the 
REVISTA DE LA UNIVERSIDAD DEL ZULIA. $3^{a}$ época. Año $13 \mathrm{~N}^{\circ}$ 36, 2022

Olha Milashovska et al. /// The potential of applying blockchain technologies in various sectors ... 288-304 DOI: http://dx.doi.org/10.46925//rdluz.36.19

development of the digital economy. In countries with a higher level of implementation of digital public services, the average indicators of Internet accessibility, human capital development, and integration of digital technologies are simultaneously higher.

Table 1. The Digital Economy and Society Index (DESI), EU countries, 2021

\begin{tabular}{|c|c|c|c|c|}
\hline Country & $\begin{array}{l}\text { Connecti } \\
\text { vity }\end{array}$ & $\begin{array}{c}\text { Digital Public } \\
\text { Services }\end{array}$ & $\begin{array}{l}\text { Human } \\
\text { Capital }\end{array}$ & $\begin{array}{c}\text { Integration of Digital } \\
\text { Technology }\end{array}$ \\
\hline Austria & 13,2476 & 19,9584 & 13,3373 & 10,3259 \\
\hline Belgium & 12,0994 & 16,4566 & 12,6955 & 12,4435 \\
\hline Bulgaria & 9,52411 & 14,012 & 8,17517 & 5,12099 \\
\hline Croatia & 11,3528 & 12,993 & 11,6806 & 9,99231 \\
\hline Cyprus & 10,4539 & 15,4553 & 9,91849 & 7,63476 \\
\hline Czechia & 11,1606 & 14,6472 & 11,7883 & 9,7681 \\
\hline Denmark & 18,5098 & 21,7714 & 15,2997 & 14,4818 \\
\hline Estonia & 11,6392 & 22,9407 & 14,4793 & 10,3657 \\
\hline $\begin{array}{l}\text { European } \\
\text { Union }\end{array}$ & 12,5403 & 17,0132 & 11,7649 & 9,39214 \\
\hline Finland & 12,817 & 21,679 & 17,7771 & 14,8735 \\
\hline France & 11,8522 & 18,248 & 11,8399 & 8,69166 \\
\hline Germany & 14,499 & 16,8684 & 13,8103 & 8,88743 \\
\hline Greece & 9,43265 & 10,4854 & 10,2603 & 7,13132 \\
\hline Hungary & 12,9993 & 12,2897 & 10,1201 & 5,82488 \\
\hline Ireland & 14,1027 & 20,652 & 13,5186 & 12,0052 \\
\hline Italy & 10,5877 & 15,7985 & 8,77886 & 10,3619 \\
\hline Latvia & 12,5948 & 19,9076 & 10,2772 & 6,6998 \\
\hline Lithuania & 10,4286 & 19,5123 & 11,5356 & 10,3024 \\
\hline Luxembourg & 15,2424 & 19,8404 & 14,046 & 9,85591 \\
\hline Malta & 13,5281 & 21,0487 & 12,2737 & 12,7111 \\
\hline $\begin{array}{l}\text { The } \\
\text { Netherlands }\end{array}$ & 17,1111 & 19,9755 & 15,3872 & 12,6746 \\
\hline Poland & 11,3289 & 13,775 & 9,4245 & 6,46908 \\
\hline Portugal & 12,1309 & 17,2369 & 11,3915 & 9,14354 \\
\hline Romania & 13,2932 & 5,37211 & 8,26281 & 5,93985 \\
\hline Slovakia & 11,5633 & 13,4307 & 10,9381 & 7,27292 \\
\hline Slovenia & 13,2983 & 16,9984 & 11,9508 & 10,5799 \\
\hline Spain & 15,5073 & 20,169 & 12,0832 & 9,68769 \\
\hline Sweden & 14,8928 & 20,9863 & 16,1388 & 14,0838 \\
\hline
\end{tabular}

Source: European Commission (2021). 
REVISTA DE LA UNIVERSIDAD DEL ZULIA. $3^{a}$ época. Año $13 \mathrm{~N}^{\circ}$ 36, 2022 Olha Milashovska et al. /// The potential of applying blockchain technologies in various sectors ... 288-304 DOI: http://dx.doi.org/10.46925//rdluz.36.19

Figure 4. Tree cluster diagram for visual representation of clusters of countries in the context of the digital economy development

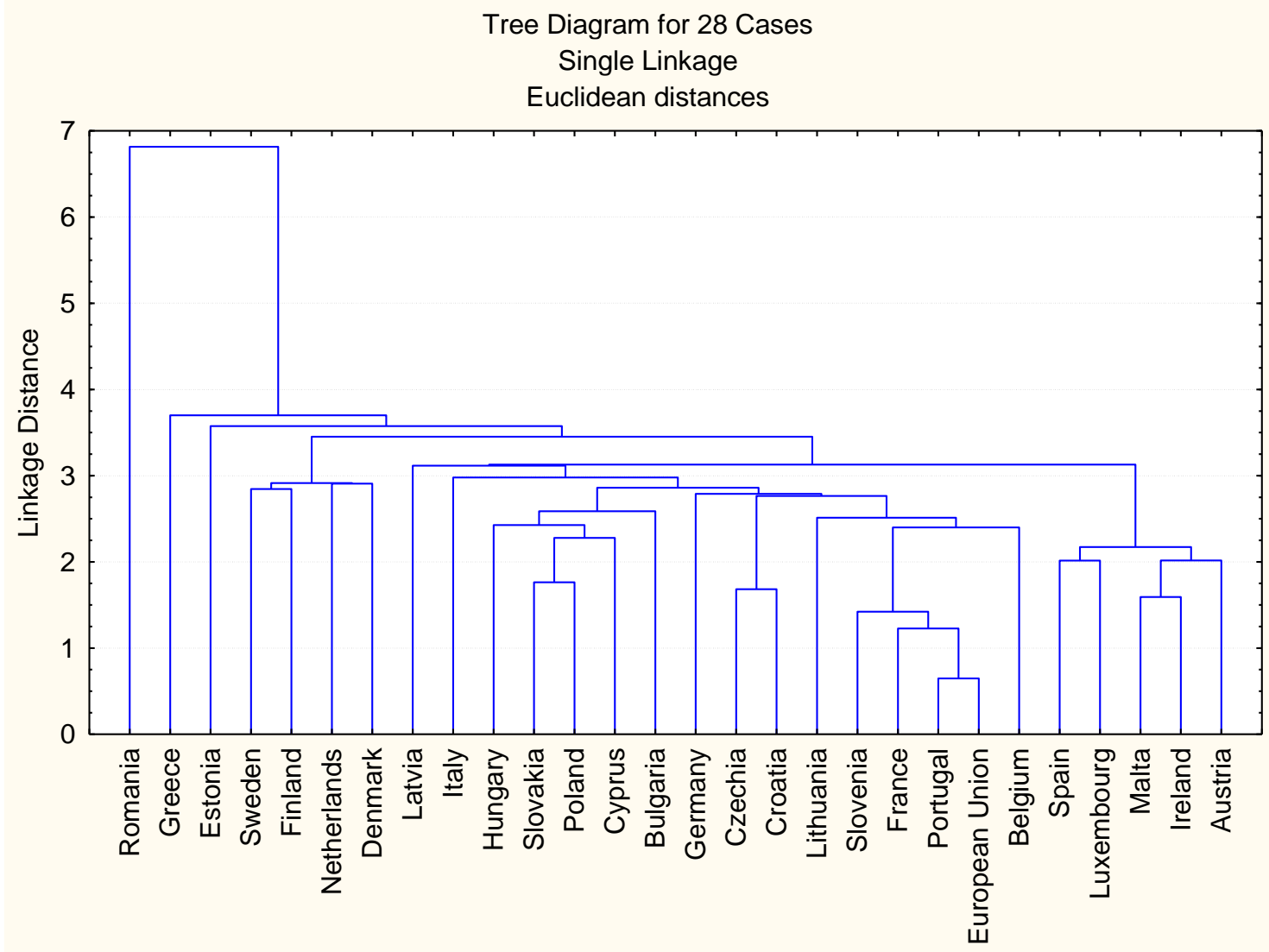

Source: compiled by the authors based on the European Commission (2021).

Table 2. Average values of indicators of digital economy development of the countries of various clusters

\begin{tabular}{|l|c|c|c|}
\hline & Mean & Standard & Variance \\
\hline \multicolumn{3}{|c|}{ l cluster } \\
\hline Connectivity & 11,91654 & 1,225463 & 1,501759 \\
\hline Digital Public Services & 16,76128 & 1,940707 & 3,766344 \\
\hline Human Capital & 11,45266 & 1,302394 & 1,696230 \\
\hline Integration of Digital Technology & 9,49145 & 1,477654 & 2,183460 \\
\hline \multicolumn{3}{|c|}{2 cluster } \\
\hline Connectivity & 14,65980 & 2,056121 & 4,227632 \\
\hline Digital Public Services & 20,90214 & 1,001115 & 1,002231 \\
\hline Human Capital & 14,43409 & 1,767834 & 3,125239 \\
\hline Integration of Digital Technology & 12,10652 & 1,972683 & 3,891479 \\
\hline \multicolumn{3}{|c|}{3 cluster } \\
\hline Connectivity & 11,35691 & 1,646328 & 2,71040 \\
\hline Digital Public Services & 11,56082 & 3,298341 & 10,87905 \\
\hline Human Capital & 9,53016 & 1,123990 & 1,26335 \\
\hline Integration of Digital Technology & 6,29317 & 0,826013 & 0,68230 \\
\hline
\end{tabular}

Source: compiled by the authors based on the European Commission (2021). 
REVISTA DE LA UNIVERSIDAD DEL ZULIA. $3^{a}$ época. Año $13 \mathrm{~N}^{\circ}$ 36, 2022

Olha Milashovska et al. /// The potential of applying blockchain technologies in various sectors ... 288-304 DOI: http://dx.doi.org/10.46925//rdluz.36.19

The conducted cluster analysis of the digital economy development of the EU countries proves that the potential for using blockchain technology in each country depends on and is associated with the introduction of different technologies, the availability of the Internet, the provision of digital services by the government, and the development of human capital.

\section{Discussion}

Blockchain as a new technology accelerates globalization processes, ensuring the country's transition from the real sector to the network sector of the economy, thereby contributing to the digital economy development (Vovchenko et al., 2017). Catalini (2017) highlights the following key transformations of the digital economy through blockchain, namely: changing established business models and existing value chains; a radical change in the nature of mediation due to a new wave of technological change; significant reduction in the cost of verifying transaction attributes that can be recorded on the blockchain and the cost of the network; the use of cryptocurrency in order to achieve consensus by economic agents on the allocation of scarce resources on a global scale.

Harris (2018) systematizes the risks of blockchain technology in underdeveloped countries as follows: risks of damage or failure, security risks due to attacks, the trend towards centralized technology management, limited user access, privacy and autonomy, legislative problems due to the need for concluding contracts, regulation and taxation, problems of scaling and storage, speed and verification. From among the main problems of blockchain implementation, Karapetyan et al. (2019) have identified as follows: gaps in legislative regulation; a significant number of projects at the development stage that have not proven their own economic feasibility; lack of full understanding of the potential for the introduction of blockchain technology, the expected results in terms of the number and timing of their receipt by government officials, business representatives, society; discussions on the circulation of cryptocurrencies in countries, their potential impact on the national economy.

The potential impact of blockchain technology on the collaborative economy (CE), or the sharing economy, may be manifested in the rapid integration of the latest technological advances, including artificial intelligence, big data analysis, augmented reality, smart grid, and blockchain technologies into different sectors of the economy (Ertz \& Boily, 2019). It 
REVISTA DE LA UNIVERSIDAD DEL ZULIA. $3^{a}$ época. Año $13 \mathrm{~N}^{\circ}$ 36, 2022

Olha Milashovska et al. /// The potential of applying blockchain technologies in various sectors ... 288-304 DOI: http://dx.doi.org/10.46925//rdluz.36.19

may be expected that blockchain will ensure the revolution in industry and commerce; it will drive economic change on a global scale forasmuch as the technology is immutable, transparent, redefining trust between economic agents, providing safe, fast, reliable and transparent solutions that can be of public or private nature (Underwood, 2016). Technology provides people in developing countries with a recognized identity, asset ownership and affordability. At the same time, blockchain prevents a recurrence of the 2008 financial crisis; it supports effective health care programs, as well as improves, optimizes, and transforms supply chains. In the future, the technology can eliminate unethical high-cost, high-value business behaviour, leading to significant intermediary costs or fraudulent risks.

\section{Conclusion}

The present research has analysed and systematized the core quantitative indicators of the digital economy of the EU countries, determining the potential of applying the blockchain technology in the EU states. The conducted cluster analysis of the digital economy development of the EU countries proves that the potential for using blockchain technology in each country depends on and is associated with the introduction of different technologies, the availability of the Internet, the provision of digital services by the government, and the development of human capital. Consequently, in countries with a high level of social-economic development, high ratings for the quality of digital public services, the development of human capital and the availability of the Internet, the simultaneous high level of integration of technologies into different sectors of the digital economy is observed (Austria, Denmark, Estonia, Finland, Ireland, Luxembourg, Malta, Netherlands, Spain, Sweden should be noted). In the future, the potential of blockchain technology will be manifested in the acceleration of globalization, technological development of countries, especially countries with a high quality of human capital, transformation of doing business and elimination of intermediation, optimization of value chains by reducing transaction costs. In the most advanced countries, economic agents will be more optimal in allocating available resources, forasmuch as the blockchain effect as a tool of eliminating the risks of corrupt fraudulent schemes will enhance the effects of a low level of corruption and a high level of trust in institutions in such countries. 
REVISTA DE LA UNIVERSIDAD DEL ZULIA. $3^{a}$ época. Año $13 \mathrm{~N}^{\circ}$ 36, 2022

Olha Milashovska et al. /// The potential of applying blockchain technologies in various sectors ... 288-304 DOI: http://dx.doi.org/10.46925//rdluz.36.19

\section{References}

Abodei, E., Norta, A., Azogu, I., Udokwu, C., \& Draheim, D. (2019, September). Blockchain technology for enabling transparent and traceable government collaboration in public project processes of developing economies. In Conference on e-Business, e-Services and eSociety (pp. 464-475). Springer, Cham. https://doi.org/10.1007/978-3-030-29374-1_38

Babkin A., V., Burkaltseva D., D., Pshenichnikov W., W., \& Tyulin A., S. (2017). Cryptocurrency and blockchain-technology in digital economy: development genesis. St. Petersburg State Polytechnical University Journal. Economics, 67(5), 9-22. https://doi.org/10.18721/JE.10501

Baralla, G., Ibba, S., Marchesi, M., Tonelli, R., \& Missineo, S. (2018, August). A blockchain based system to ensure transparency and reliability in food supply chain. In European conference on parallel processing (pp. 379-391). Springer, Cham. https://doi.org/ 10.1007/978-3030-10549-5_30

Barefoot, K. et al. (2018). Defining and measuring the digital economy. US Department of Commerce Bureau of Economic Analysis, Washington, DC. T. 15. https:/www.bea.gov/system/files/papers/WP2018-4.pdf

Bhimani, A., Hausken, K., \& Arif, S. (2021). Blockchain Technology Adoption Decisions: Developed vs. Developing Economies. In Information for Efficient Decision Making: Big Data, Blockchain and Relevance (pp. 91-113). https://doi.org/10.1142/9789811220470_0003

Britchenko, I., \& Cherniavska, T. (2019). Blockchain Technology in the Fiscal Process of Ukraine. $\quad$ Economic $\quad$ Studies, 28 https://ideas.repec.org/a/bas/econst/y2019i5pl34-147.html

(5), $134-148$.

Bukht, R. \& Heeks, R. (2017). Defining, conceptualising and measuring the digital economy. Development Informatics working paper, 68. https://dx.doi.org/10.2139/ssrn.3431732

Catalini, C. (2017). How blockchain technology will impact the digital economy. Blockchains Smart Contracts Internet Things, 4, 2292-2303. https:/www.law.ox.ac.uk/business-lawblog/blog/2017/04/how-blockchain-technology-will-impact-digital-economy

Corallo, A., Paiano, R., Guido, A. L., Pandurino, A., Latino, M. E., \& Menegoli, M. (2018, June). Intelligent monitoring Internet of Things based system for agri-food value chain traceability and transparency: A framework proposed. In 2018 IEEE Workshop on Environmental, Energy, and Structural Monitoring Systems (EESMS) (pp. 1-6). IEEE. https://doi.org/10.1109/EESMS.2018.8405814

Crosby, M., Pattanayak, P., Verma, S., \& Kalyanaraman, V. (2016). Blockchain technology: Beyond bitcoin. Applied Innovation, 2(6-10), 71 .

Dorofeyev, M., Kosov, M., Ponkratov, V., Masterov, A., Karaev, A., \& Vasyunina, M. (2018). Trends and prospects for the development of blockchain and cryptocurrencies in the digital economy. European Research Studies Journal, 21(3), 429-445. https://doi.org/10.35808/ersj/1073 
REVISTA DE LA UNIVERSIDAD DEL ZULIA. $3^{a}$ época. Año $13 \mathrm{~N}^{\circ}$ 36, 2022

Olha Milashovska et al. /// The potential of applying blockchain technologies in various sectors ... 288-304 DOI: http://dx.doi.org/10.46925//rdluz.36.19

Efanov, D., \& Roschin, P. (2018). The all-pervasiveness of the blockchain technology. Procedia computer science, 123, 116-121. https://doi.org/10.1016/j.procs.2018.01.019

Ertz, M., \& Boily, É. (2019). The rise of the digital economy: Thoughts on blockchain technology and cryptocurrencies for the collaborative economy. International Journal of Innovation Studies, 3(4), 84-93. https://doi.org/10.1016/j.ijis.2019.12.002

European Commission (2021). The Digital Economy and Society Index (DESI). Available at: https://digital-strategy.ec.europa.eu/en/policies/desi

Eurostat (202la). Percentage of the ICT sector in GDP. Available at: https://appsso.eurostat.ec.europa.eu/nui/show.do?dataset=isoc bdel5ag\&lang=en

Eurostat (2021b). Percentage of the ICT personnel in total employment. Available at: https://appsso.eurostat.ec.europa.eu/nui/show.do?dataset=isoc bdel5ap\&elang=en

Eurostat (202lc). Employed ICT specialists - total. Available at: https://appsso.eurostat.ec.europa.eu/nui/show.do?dataset=isoc sks itspt\&elang=en

Eurostat (202ld). Individuals - internet use. Available at: https://appsso.eurostat.ec.europa.eu/nui/show.do?dataset=isoc ci ifp iu\&lang=en

Eurostat (202ld). Use of ICT at work and activities performed. Available at: https://appsso.eurostat.ec.europa.eu/nui/show.do?dataset=isoc iw ap\&elang=en

Eurostat (202le). Internet purchases by individuals (2020 onwards). Available at: https://appsso.eurostat.ec.europa.eu/nui/show.do?dataset=isoc ec ib20\&lang=en

Góźdź, K. J. \& Van Oosterom, P. J. M. (2016). Developing the information infrastructure based on LADM-the case of Poland. Survey review, 48 (348), 168-180. https://doi.org/10.1179/1752270615Y.0000000018

Harris, C. G. (2018, April). The risks and dangers of relying on blockchain technology in underdeveloped countries. In NOMS 2018-2018 IEEE/IFIP Network Operations and Management Symposium (pp. 1-4). IEEE. http://dx.doi.org/10.1109/NOMS.2018.8406330

International Monetary Fund (2018). Measuring the digital economy. IMF Policy Papers. https:/www.imf.org/en/Publications/Policy-Papers/Issues/2018/04/03/022818-measuringthe-digital-economy

Karapetyan, M., Timoshenko, L., Stroganov, I., \& Pronina, I. (2019). The development of blockchain technology in Russia: outlook and trends. International Journal of Economics \& Business Administration, 7(2), 279-289. https://doi.org/10.35808/ijeba/244

Kwok, A. O., \& Koh, S. G. (2019). Is blockchain technology a watershed for tourism development? Current Issues in 2447-2452. https://doi.org/10.1080/13683500.2018.1513460 
REVISTA DE LA UNIVERSIDAD DEL ZULIA. $3^{a}$ época. Año $13 \mathrm{~N}^{\circ}$ 36, 2022

Olha Milashovska et al. // The potential of applying blockchain technologies in various sectors ... 288-304 DOI: http://dx.doi.org/10.46925//rdluz.36.19

Muminova, E., Honkeldiyeva, G., Kurpayanidi, K., Akhunova, S., \& Hamdamova, S. (2020). Features of Introducing Blockchain Technology in Digital Economy Developing Conditions in Uzbekistan. In E3S Web of Conferences (Vol. 159, p. 04023). EDP Sciences. https://doi.org/10.1051/e3sconf/202015904023

Sajja, G. S., Rane, K. P., Phasinam, K., Kassanuk, T., Okoronkwo, E., \& Prabhu, P. (2021). Towards applicability of blockchain in agriculture sector. Materials Today: Proceedings. https://doi.org/10.1016/j.matpr.2021.07.366

Szeles, M. R. \& Simionescu, M. (2020). Regional Patterns and Drivers of the EU Digital Economy. Social Indicators Research, 1-25. https://doi.org/10.1007/sll205-020-02287-x

Treiblmaier, H., Leung, D., Kwok, A. O., \& Tham, A. (2020). Cryptocurrency adoption in travel and tourism-an exploratory study of Asia Pacific travellers. Current Issues in Tourism, 117. https://doi.org/10.1080/13683500.2020.1863928

Tripoli, M., \& Schmidhuber, J. (2018). Emerging Opportunities for the Application of Blockchain in the Agri-food Industry. FAO and ICTSD: Rome and Geneva. Licence: CC BY-NC-SA, 3. https://www.fao.org/3/ca9934en/CA9934EN.pdf

UNCTAD. (2019). Digital economy report 2019: Value creation and capture-Implications for developing countries. Geneva.

Underwood, S. (2016). Blockchain beyond bitcoin. Communications of the ACM, 59(11), 15-17. https://doi.org/10.1145/2994581

Vovchenko, N. G., Andreeva, A. V., Orobinskiy, A. S., \& Filippov, Y. M. (2017). Competitive advantages of financial transactions on the basis of the blockchain technology in digital economy. European Research Studies, 20(3B), 193.

Yeoh, P. (2017). Regulatory issues in blockchain technology. Journal of Financial Regulation and Compliance. Vol. 25(2), 196-208. https://doi.org/ 10.1108/JFRC-08-2016-0068 